\title{
Medicolegal Evaluation of the Case of Implantable Cardioverter Defibrillator (ICD) Lead Fracture Due to Domestic Violence
}

\author{
Aile İçi Şiddet Sonrası İmplante Cardioverter Defibrillator (ICD) Lead Fraktürü Meydana Gelen \\ Olgunun Medikolegal Değerlendirmesi
}

\author{
Ahsen KAYA \\ (i) 0000-0002-6969-1562 \\ Cemil ÇELIK \\ (D) 0000-0002-8103-459X \\ Hülya GÜLER \\ (D) 0000-0002-3205-4113 \\ Ender ŞENOL \\ (1) 0000-0001-9018-2466 \\ Ekin Özgür AKTAŞ \\ (D) 0000-0003-0934-3731
}

Ege University Faculty of Medicine Department of Forensic Medicine, İzmir, Turkey

\begin{abstract}
There has been an increase in sudden cardiac death in recent years. Lately, implantable cardioverter defibrillator (ICD) is a device which is used to prevent sudden cardiac death. Some problems may occur in the device as a result of trauma. Lead fracture constitutes one of these problems. In the literature, blunt trauma-related ICD complications, particularly lead fracture, seem to be very rare. In this case report, we evaluated a female patient who was exposed to a blunt trauma while getting pulled her left arm by her ex-husband and to some inappropriate shocks due to lead fracture, in medicolegal aspect. In case, a lead fracture occurred by pulling her left arm without chest trauma. It is aimed to take importance that even a mild violence might cause life-threating, severe clinical outcome.

Keywords: Partner violence; blunt trauma; sudden death; medicolegal evaluation; implantable
\end{abstract} cardioverter defibrillator.

öz

Son yıllarda ani kardiyak ölüm oranlarında artış görülmektedir. Günümüzde, implante edilebilir kardiyoverter defibrilatör (implantable cardioverter defibrilator, ICD) ani kardiyak ölümleri önlemede kullanılan bir cihazdır. Travma sonucunda cihazda birtakım problemler meydana gelebilmektedir. Kablo kırığı bu problemlerden biridir. Literatürde, künt travmaya bağlı ICD komplikasyonlarının, özellikle kablo kırığının oldukça nadir görüldüğü belirtilmektedir. $\mathrm{Bu}$ olgu sunumunda; eski eşi tarafindan sol kolu çekilerek künt travmaya maruz kalan ve oluşan kablo kırığı nedeniyle uygunsuz şoklara maruz kalan kadın olgu medikolegal açıdan değerlendirildi. Olguda, göğse direkt bir travma olmadan, sol kolun çekilmesine bağlı olarak lead kırığı meydana gelmiştir. Hafif şiddetteki bir travmanın bile, yaşamsal tehlike oluşturabilecek, ciddi klinik sonuçlara neden olabileceğine dikkat çekmek amaçlandi.

Anahtar kelimeler: Partner şiddeti; künt travma; ani ölüm; adli-tıbbi değerlendirme; implante edilebilir kardiyoverter defibrilatör.

\section{INTRODUCTION}

Recently, there has been an increase in sudden cardiac death. Implantable cardioverter defibrillator (ICD) is a device used to prevent sudden cardiac death nowadays (1). Nevertheless, it is underlined that an appropriate patient selection is significant due to cost and potential complications (2). During the perioperative period, there are risks of various complications such as the removal of the lead wires of the ICD's to the heart, pneumothorax, infection, and bleeding, whereas, in the long term, inappropriate shocks (3). The complications that may lead to death related to ICD are rare. The rate of ICD complications that lead to the change of device

Received / Geliş Tarihi : 05.05.2020 Accepted / Kabul Tarihi : 25.06.2020 Available Online /

Presented as an oral presentation at the $2^{\text {nd }}$ International Turaz Forensic Sciences, Legal Medicine and Çevrimiçi Yayın Tarihi : 25.08.2020 Pathology Congress, September 1-4, 2018, Istanbul, Turkey 
and surgical revision maintains its importance clinically despite remarkable developments in ICD technology $(2,4)$. Though an inappropriate shock incidence, which is one of the ICD complications, shows alterations in different studies, it often occurs between $4-25 \%$, and it is associated with the increase in morbidity (5-7). Inappropriate shocks, mostly get origin from supraventricular tachycardia, selfterminating ventricular tachycardia, sensing artifacts, myopotentials or $\mathrm{T}$ wave oversensing $(2,6)$. In addition to these, trauma can also be a reason for these inappropriate shocks $(2,4)$. From a medicolegal perspective, it's significant to identify what clinical consequences that the trauma causes. In patients with ICD, various problems may occur such as dislodgement of the lead, lead fracture, device header fracture as a result of mechanical chest trauma. Even though, lead fracture, constituting one of these problems, occurs rarely, it may result in inappropriate shocks, loss of pacing, failure of defibrillation or fatal proarrhythmia (8-11).

In this case report, a female patient, who was exposed to blunt trauma while getting pulled her left arm and to some inappropriate shocks resulting from lead fracture was evaluated in medicolegal aspect. It is aimed to take importance that even a mild violence might cause lifethreating, severe clinical outcome.

\section{CASE REPORT}

A 50-year-old female case, who was battered by her exhusband, appealed to our department for the preparation of her forensic report. She was examined after her informed consent was obtained.

The patient reported that she was diagnosed with dilated cardiomyopathy and left bundle branch block and planted a pacemaker, five years ago. She stated that, she was arguing with her ex-husband on the date of the incident. Then, he pulled her left arm and she felt a severe pain from her left arm to her chest. She had not been exposed to another trauma. She continued to feel the pain at that night, she heard a sound from her pacemaker during sleep, which is like a tick-tack sound coming from a clock, and she felt something like an electric shock on her body twice before applying to a health center the next day.

It was observed in her medical documents that the device was alerted and there were inappropriate shocks due to ICD lead fracture one day after the incident. It was also apparent in the documents that there was no clinical pathology and the device was shut down and then she was referred to a university hospital.

After her application to our department, a consultation was requested from the department of cardiology. Cardiology consultation note indicated that the patient had a Medtronic Cardiac Resynchronization Battery/Defibrillator (CRT-D) device and Medtronic 6944-A cable was used as a defibrillation cable. Impedance height ( $>3000 \mathrm{Ohms})$ and inappropriate shocks, which indicate the fact that the cable was broken, were detected in the device controls. It was also reported that the broken cable was changed with a new cable and the ICD battery life about to be out was replaced. The forensic report of the case was prepared in the light of the medical documents, the comprehensive medical anamnesis taken from the patient, her examination and cardiology consultation report.

\section{DISCUSSION AND CONCLUSIONS}

In the present case, a lead fracture occurred by pulling the case's left arm without chest trauma. This case has revealed that even a seemingly slight violence, such as pulling arm, can have serious life-threatening consequences. In the literature, blunt trauma-related ICD complications, particularly lead fracture, seem to be very rare (8). Furthermore, in the literature, there is a case of ICD complication (header fracture) resulting from a deceleration injury in a car accident without chest trauma (9). Therefore, it should be taken into consideration that ICD will fail even if there is no significant blunt chest trauma in patients with ICD. It is significant for the prevention of poor clinical outcomes. In addition to this, we realize the significance of the fact that patients with ICD are to be placed under remote device monitoring and the devices should be re-inspected after such traumas.

In this case, the device was shut down following inappropriate shocks triggered by trauma and it was replaced by the new one for some time later. Inappropriate shocks can lead to arrhythmias and the shortening of the battery life $(2,4)$. In order to prevent the occurrence of ventricular tachycardia/fibrillation during the acute care of the patients with inappropriate shocks who applied to any health care provider, ICD should be immediately deactivated. During the time slot between the shutting down of a device emanating inappropriate shocks and the implantation of the new one, it is of significance to monitor and follow up patients in order to detect such complications as arrhythmia. It is also significant on the one hand for an early diagnosis and treatment; and, on the other, for a medicolegal evaluation in forensic cases.

All modern pacemakers/ICDs constitute an internal memory in order to retain information during interventions and to hide the long-term information (mostly $24 \mathrm{~h}$ ). The whole information regarding the interventions is stored in this memory in order to enable post-traumatic diagnosis. Nevertheless, ICDs are unable to differentiate between a cardiac-related arrhythmia and the findings stemming from any fracture within the electrode system (12). The occurrence of arrhythmia is probable among the patients who are subjected to inappropriate shocks. From a medicolegal perspective, it is notable to detect this and to differentiate the shocks triggered by the device from those which are cardiac related. Therefore, particularly in forensic cases, it is highly significant to document and retain the ICD information of patients, which are legible. These documents are significant in that they enable to reply to potential allegations to be put forward particularly in forensic cases and to identify the cause of death in mortal cases

According to Turkish Penal Code (TPC), it was evaluated that the event did not endanger her life, as it did not cause any cardiac disorders such as cardiac rhythm disturbances that could endanger a person's life and there were not any clinical signs which show affecting of circulatory, respiratory or central nervous system functions in her medical records. At the same time, it was concluded that the effect of this intentional injury upon a person was not minor and could not be cured by a simple medical treatment due to the fact that the person required a medical intervention (replacing the battery and the broken lead). Although the present event did not cause a life-threatening 
situation by chance according to TPC, it is valuable to point out that without direct regional trauma, indirect trauma can cause damaging of instruments that were used for medical purposes, and this damage may lead to lifethreatening conditions according to the properties and intended usage of the device.

\section{REFERENCES}

1. Ezekowitz JA, Rowe BH, Dryden DM, Hooton N, Vandermeer B, Spooner C, et al. Systematic review: implantable cardioverter defibrillators for adults with left ventricular systolic dysfunction. Ann Intern Med. 2007;147(4):251-62.

2. Alter P, Waldhans S, Plachta E, Moosdorf R, Grimm W. Complications of implantable cardioverter defibrillator therapy in 440 consecutive patients. Pacing Clin Electrophysiol. 2005;28(9):926-32.

3. Kron J, Herre J, Renfroe EG, Rizo-Patron C, Raitt M, Halperin B, et al. Lead- and device-related complications in the antiarrhythmics versus implantable defibrillators trial. Am Heart J. 2001;141(1):92-8.

4. Yaminisharif A, Soofizadeh N, Shafiee A, Kazemisaeid A, Jalali A, Vasheghani-Farahani A. Generator and lead-related complications of implantable cardioverter defibrillators. Int Cardiovasc Res J. 2014;8(2):66-70.
5. Jarman JWE, Lascelles $\mathrm{K}$, Wong $\mathrm{T}$, Markides V, Clague JR, Till J. Clinical experience of entirely subcutaneous implantable cardioverter-defibrillators in children and adults: cause for caution. Eur Heart J. 2012;33(11):1351-9.

6. Messali A, Thomas O, Chauvin M, Coumel P, Leenhardt A. Death due to an implantable cardioverter defibrillator. J Cardiovasc Electrophysiol. 2004;15(8):953-6.

7. Pinski SL, Fahy GJ. The proarrhythmic potential of implantable cardioverter-defibrillators. Circulation. 1995;92(6):1651-64.

8. Böhm A, Duray G, Kiss RG. Traumatic pacemaker lead fracture. Emerg Med J. 2013;30(8):686.

9. Barakat AF, Cross B, Wertz J, Saba S, Kancharla K. Cardiac implantable electronic device malfunction after deceleration injury without obvious chest trauma. HeartRhythm Case Rep. 2019;5(5):285-7.

10. Catanchin A, Anderson L, Jones S, Ward D. When lifesaving devices terminate life. J Cardiovasc Electrophysiol. 2008;19(3):316-8.

11. Chen WL, Chen YJ, Tsao YT. Traumatic pacemaker lead fracture. J Trauma. 2010;69(4):E34.

12. Junge $M$, Weckmüller $J$, Nägele $H$, Püschel $K$. "Natural death" of a patient with a deactivated implantable-cardioverter-defibrillator (ICD)? Forensic Sci Int. 2002;125(2-3):172-7. 